fit patients and society at large. I have heard distinguished academics deliver distorted and limited descriptions of a topic in support of their research, and physicians paid by government agencies often deliver messages that clearly pander to the payer and not to scientific honesty.

To mention just one example, the "commercial moral syndrome" has delivered biologic agents that have transformed the treatment of inflammatory arthritis. If that syndrome has also resulted in monetary profit, is that sinful? Many of the advances in therapeutics, both medical and surgical, would not have occurred without the beckoning of "tawdry profit."

It is surely our responsibility as professionals to analyze and critique any information that we might be given, or that we might search out on our own, to formulate the best synthesis of the data. If we are to be restricted by a sanctimonious few to the information that those few consider "appropriate," we are victims of censorship.

I wonder about the fate of publications such as $C M A J$ if the proposals in this editorial were enacted. What would the subscription price be? How would the many editors be paid? Who would be the arbiter of those who are deemed to possess the "guardian moral syndrome" and, accordingly, who would be allowed to educate us all?

The system of continuing medical education and medical publishing as it currently exists is democratic. And, like a democratic political system, it is imperfect but better than anything else.

\section{Barry Koehler}

Consultant in Rheumatology

Richmond, BC

\section{REFERENCE}

I. Is medicine still a profession? [editorial]. CMAJ 2006;174(6):743.

DOI:I0.1503/cmaj.1060077

In the same issue as an editorial that explicitly asks "Is medicine still a profession?" 1 appear 2 articles that seem to answer this question in the negative, considering that the controversial prac- tices of the Don Coleman clinic in Vancouver ${ }^{2}$ seem to be agreed upon by "two-tier-Tony" (Canada's new minister of health, Tony Clement) ${ }^{3}$ and are to spread across all of Canada.

The gradual change of medicine from a profession of dedicated and principled physicians, who in times of war have put their health and their own lives in danger while unconditionally serving the wounded of all nations and of all creeds, into a profit-oriented in- dustry may represent a reflection of the profit-oriented politics of foreign affairs, as was candidly admitted by Sir Winston Churchill in 1946 on the occasion of his visit with the former US president H.S. Truman and a speech at Westminster College, in Fulton, Mo.

We still have not learned the lessons of history, and we are paying a bitter price for it in politics and in medicine. Our opinions about private and statecontrolled health care may differ, but it 
is high time to realize that the way medicine is practised depends on our own conduct. If we truly believe in basic unalienable principles, we have no choice but to act upon them. Salus aegroti suprema lex - the welfare of the patient should be the ultimate goal of our professional services. Then, state and private health care could peacefully coexist because both would have the welfare of patients in mind.

\section{Wilhelm Kreyes}

Retired Physician

Winnipeg, Man.

\section{REFERENCES}

I. Is medicine still a profession? [editorial]. CMAJ 2006; $174(6): 743$.

2. Kondro W. Copeman clinics come under scrutiny. CMAJ 2006;174(6): 753

3. Kondro W, Sibbald B. Tony Clement appointed as Canada's new health minister. CMAJ 2006;174(6): 754 .

DOI:Io.I503/cmaj.1060079

CMAJ's editorial on the topic of whether medicine is still a profession ${ }^{1}$ states that the core values of the medical profession are integrity, compassion, altruism and excellence, but in my view these values have eroded over the past few decades.

For example, the most visible characteristic of modern medicine is excellence, but this quality is seen by the profession and the public alike as mere technical achievement. The practising physician relies heavily on positive PR from this cutting-edge image, and each media account of a medical breakthrough is a welcome ray of sunshine in the progressively dimming world of what is now recognized as the "sickness industry."

People have discovered that doctors are people, too - wealthy ones, more often than not. People have also discovered that if you poke any saint deep enough, you will soon touch self-interest. There goes the aura of altruism and compassion.

The editorial says that we need to "restore the scientific integrity of medicine." Perhaps we would be well advised to work on the personal integrity of individual doctors, since so many of them have found a new home in the deep pockets of Big Pharma.
The word "humane" has disappeared from many sectors of society, including medicine. This concept needs to be brought back to replace the devils of indifference and greed. As additional reading on this subject, I highly recommend Petr Skrabanek's The Death of Humane Medicine and the Rise of Coercive Healthism. ${ }^{2}$

\section{Herbert H. Nehrlich \\ Private Practice \\ Bribie Island, Australia}

\section{REFERENCES}

I. Is medicine still a profession? [editorial]. CMAJ 2006;174(6):743

2. Skrabanek P. The Death of Humane Medicine and the Rise of Coercive Healthism. Social Affairs Unit, London, UK 1994.

DOI:I0.I503/cmaj.1060082

\section{Patient characteristics}

\section{not described}

Research based on administrative databases, such as that reported by Scot Simpson and associates, ${ }^{1}$ who investigated the dose-response relation between sulfonylurea drugs and death in a patient with type 2 diabetes mellitus, can demonstrate trends but may not provide sufficient detail about individual patient variables. In treating newonset diabetes, many physicians might be expected to initially prescribe metformin for obese patients and glyburide for patients of normal weight. ${ }^{2}$ However, the research reported by Simpson and associates does not allow us to confirm or refute such possible trends. Is the greater mortality rate associated with glyburide partially attributable to the more severe insulin deficiency seen in normal-weight diabetic patients, rather than being related to the type of antidiabetic drug used?

Simpson and associates did not determine mortality rates for patients receiving dual metformin and glyburide therapy. Thus, there was no opportunity to observe any possible protective effect of combined therapy.

At a more practical level, this study may convince physicians to switch to other, less common sulfonylureas or thiazolidinediones. However, many pa- tients covered by provincial drug plans may have limited access to payment for such drugs. Provincial drug programs will need to move quickly to accommodate such shifts in prescribing practice to avoid financial pressures on our patients.

\section{Stanley Lofsky \\ Family Physician \\ Toronto, Ont.}

\section{REFERENCES}

I. Simpson SH, Majumdar SR, Tsuyuki RT, et al. Dose-response relation between sulfonylurea drugs and mortality in type 2 diabetes mellitus: population-based cohort study. CMAJ 2006 ; I74(2): I69-74.

2. Cheng AYY, Fantus IG. Oral antihyperglycemic therapy for type 2 diabetes mellitus. CMAJ 2005 I72(2):213-26.

DOI:Io.I503/cmaj.Io60078

\section{Corrections}

A sentence in the Results section of the abstract on page $\mathrm{I} 42 \mathrm{I}^{1}$ accidentally reversed the intended meaning of the data comparison for the primary end points of the study. It should read, "Results: The efficacy end point (a composite of 30-day mortality, reinfarction or refractory ischemia) was $12.2 \%$ with enoxaparin versus $16.0 \%$ with unfractionated heparin $(p<0.00 \mathrm{I})$; the combined end point of efficacy plus safety (a composite of 30-day mortality, reinfarction, refractory ischemia, intracranial hemorrhage [ICH] or major systemic bleeding) was $15.0 \%$ versus I $8.0 \%$, respectively $(p=0.003) . "$

\section{REFERENCE}

I. Armstrong PW, Chang WC, Wallentin L, et al. Efficacy and safety of unfractionated heparin versus enoxaparin: a pooled analysis of ASSENT- 3 and -3 PLUS data. CMAJ 2006;174(I0):I42I-6.

DOI:Io.1503/cmaj.060639

In the obituary notice for Dr. Harald Stolberg, his date of death was mistakenly listed as $84 .{ }^{1}$ The doctor died at age 79 .

\section{REFERENCE}

I. Deaths. CMAJ 2005;172(I3):1755

DOI:Io.I503/cmaj.060640 